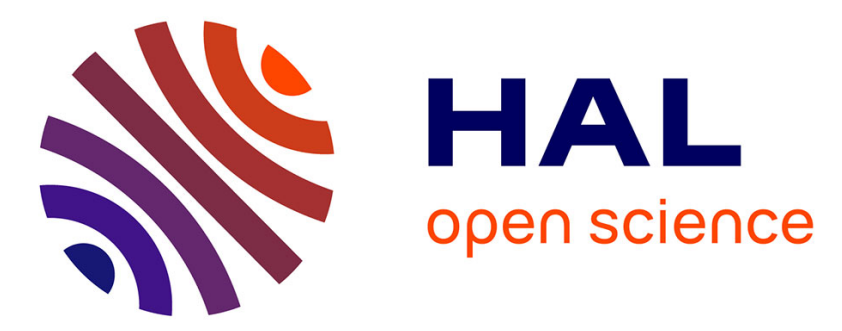

\title{
Magnetostratigraphy of the Hominin Sites and Paleolakes Drilling Project (HSPDP) Baringo-Tugen Hills-Barsemoi core (Kenya)
}

Mark Sier, Guillaume Dupont-Nivet, Cor Langereis, Alan Deino, John Kingston, Andrew Cohen

\section{To cite this version:}

Mark Sier, Guillaume Dupont-Nivet, Cor Langereis, Alan Deino, John Kingston, et al.. Magnetostratigraphy of the Hominin Sites and Paleolakes Drilling Project (HSPDP) Baringo-Tugen HillsBarsemoi core (Kenya). Palaeogeography, Palaeoclimatology, Palaeoecology, 2021, 570, pp.110190. 10.1016/j.palaeo.2020.110190 . insu-03093656

\section{HAL Id: insu-03093656 https://hal-insu.archives-ouvertes.fr/insu-03093656}

Submitted on 4 Jan 2021

HAL is a multi-disciplinary open access archive for the deposit and dissemination of scientific research documents, whether they are published or not. The documents may come from teaching and research institutions in France or abroad, or from public or private research centers.
L'archive ouverte pluridisciplinaire HAL, est destinée au dépôt et à la diffusion de documents scientifiques de niveau recherche, publiés ou non, émanant des établissements d'enseignement et de recherche français ou étrangers, des laboratoires publics ou privés. 


\section{Journal Pre-proof}

Magnetostratigraphy of the Hominin Sites and Paleolakes Drilling Project (HSPDP) Baringo-Tugen Hills-Barsemoi core (Kenya)

Mark J. Sier, Guillaume Dupont-Nivet, Cor Langereis, Alan L. Deino, John D. Kingston, Andrew S. Cohen

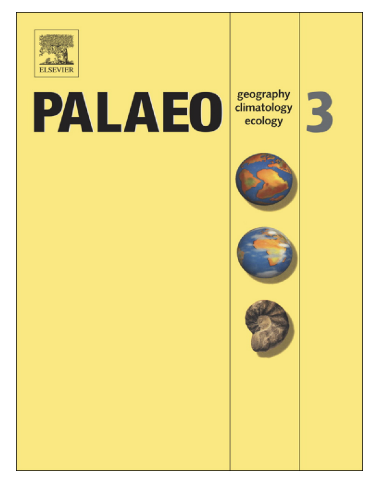

PII: $\quad$ S0031-0182(20)30638-6

DOI: $\quad$ https://doi.org/10.1016/j.palaeo.2020.110190

Reference: $\quad$ PALAEO 110190

To appear in: $\quad$ Palaeogeography, Palaeoclimatology, Palaeoecology

Received date: $\quad 11$ February 2019

Revised date: $\quad 30$ November 2020

Accepted date: 18 December 2020

Please cite this article as: M.J. Sier, G. Dupont-Nivet, C. Langereis, et al., Magnetostratigraphy of the Hominin Sites and Paleolakes Drilling Project (HSPDP) Baringo-Tugen Hills-Barsemoi core (Kenya), Palaeogeography, Palaeoclimatology, Palaeoecology (2020), https://doi.org/10.1016/j.palaeo.2020.110190

This is a PDF file of an article that has undergone enhancements after acceptance, such as the addition of a cover page and metadata, and formatting for readability, but it is not yet the definitive version of record. This version will undergo additional copyediting, typesetting and review before it is published in its final form, but we are providing this version to give early visibility of the article. Please note that, during the production process, errors may be discovered which could affect the content, and all legal disclaimers that apply to the journal pertain.

(C) 2020 Published by Elsevier. 


\section{Magnetostratigraphy of the Hominin Sites and Paleolakes Drilling Project (HSPDP) Baringo-Tugen Hills-Barsemoi core (Kenya)}

Mark J. Sier ${ }^{1,2,3, *}$ marksier@gmail.com, Guillaume Dupont-Nivet ${ }^{4,5}$, Cor Langereis ${ }^{2}$, Alan L. Deino ${ }^{6}$, John D. Kingston ${ }^{7}$, Andrew S. Cohen ${ }^{8}$

${ }^{1}$ CENIEH, Paseo Sierra de Atapuerca 3, 09002 Burgos, Spain

${ }^{2}$ Paleomagnetic Laboratory Fort Hoofddijk, Faculty of Geosciences, Utrecht University, 3584

CD, Utrecht, The Netherlands

${ }^{3}$ Department of Earth Sciences, University of Oxford, South Park Road, OX1 3AN Oxford, United Kingdom

${ }^{4}$ Geosciences Rennes UMR-CNRS 6118, Bat.15 CS 74205, 263 Avc vue du General Leclerc

Campus de Beaulieu, 35042 Rennes Cedex France

${ }^{5}$ Potsdam University, Department of Earth and Environment $1 \mathrm{Sc}$ ences, Karl-Liebknecht

Strasse 24-25; 14476 Potsdam-Golm; Germany

${ }^{6}$ Berkeley Geochronology Center, Berkeley, CA 94709 ¿'A A

${ }^{7}$ Department of Anthropology, University of Michigar, Anr Arbor, MI 48109, USA

${ }^{8}$ Department of Geosciences, University of Arizona, T'،csu? AZ 85721, USA

${ }^{*}$ Corresponding author.

\section{Abstract}

The principal objective of the Hominı. Sites and Paleolakes Drilling project (HSPDP) is to study the relationship between $c^{1}$ mate and environmental change and the implications on human evolı tı ? in eastern Africa. For this purpose, HSPDP has recovered a 228 meter core $\eta \eta$ lie Chemeron Formation of the Baringo Basin (Kenya). The Chemeron Forma+ivas syans approximately 3.7 Myr, from around 1.6 to 5.3 Ma, and has yielded many vt. ${ }^{+} e_{\text {u }}$ ate fossils, including fossil hominins. The magnetostratigraphy of the Baringo core cuitributes to the chronological framework. A total of 567 individual paleomagnetic samples were collected from 543 levels at regular intervals throughout the core and 264 were processed using thermal and alternative field stepwise demagnetizations. In most samples, distinct Low-Temperature (LT; 20-150 ${ }^{\circ} \mathrm{C}$ ) and High-Temperature $\left(\mathrm{HT} ; 150-550^{\circ} \mathrm{C}\right)$ Characteristic Remanent Magnetization $(\mathrm{ChRM})$ could be determined. Typical demagnetization behaviors and some rock magnetic experiments suggest titanomagnetite acts as the main carrier of the HT ChRM with pervasive secondary overprints in normal polarity expressed by the LT component. Normal and reversed polarities were identified based on the secondary overprints LT 
ChRM directions, either parallel or antiparallel to the HT ChRM directions respectively. Our study identified four paleomagnetic reversals interpreted as the Matuyama-Gauss, Gauss-Kaena, Kaena-Gauss and the Gauss-Mammoth transitions. These boundaries provide chronostratigraphic tie-points that can be combined with those derived from ${ }^{40} \mathrm{Ar} /{ }^{39} \mathrm{Ar}$ dating of tuffs (Deino et al., this issue) and together indicate that the HSPDP Baringo core has an age range of $\sim 3.3 \mathrm{Ma}$ to $\sim 2.6 \mathrm{Ma}$. The consistent paleomagnetic and radioisotopic age constraints are incorporated into a Bayesian age model of the core (Deino et al., this issue).

\section{Keywords}

ICDP, Lower Matuyama, Gauss, Kaena, Mammoth, Drillcore or. ${ }^{n t}$ ‘tion 


\section{Introduction}

Many evolutionary changes in the human lineage are argued to have been strongly influenced by changes in the climatic and environmental conditions (e.g. Behrensmeyer, 2006; Joordens et al., 2011; Vrba, 1995). Understanding the relationship between paleoclimatic/paleoenvironmental variation and evolutionary change is one of the key scientific questions in the field of human evolution. The Hominin Sites and Paleolakes Drilling Project (HSPDP) addresses this question by reconstructing the paleoclimate and paleoenvironment record at targeted sites in the East Africa Rift System (Campisano et al., 2017; Cohen et al., 2016). These sites in Kenya and Ethiopia correspond both in space and in time to important periods $c$. IIr volutionary past. A total of over $2 \mathrm{~km}$ of sediment cores has been recovered $\ldots$... (Campisano et al., 2017; Cohen et al., 2016). Precise ( hru_-_stratigraphic control of the cores is essential for establishing potential links b $\in$ iwe $n$ paleoclimate, paleoenvironment, and evolution.

The main aim of this paper is to present $t^{\prime} \mathrm{e}$ nagnetostratigraphic interpretation of the 228 meter long Baringo-Tugen Hil's-1 ars moi (BTB13) core drilled in 2013. The estimated age range targeted for the $\mathrm{Bl}_{\llcorner} 13$ core was 3.3 to $2.6 \mathrm{Ma}$ (Cohen et al., 2016). Within this time period many importa't events and transitions occurred in terms of human evolution and climate. At $\sim 4$ Ma the earliest evidence for processing meat has been identified in Dikika, Ethı nia (McPherron et al., 2010), followed by the earliest known stone tool technolos.", i:e Lomekwian, at around 3.3 Ma (Harmand et al., 2015). Another major transition ou ars at around 2.6 Ma when the more widespread Oldowan

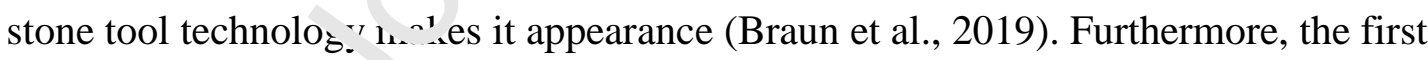
appearance of the ge $\cdots$ Homo at $2.8 \mathrm{Ma}$ (Villmoare et al., 2015) and Paranthropus (Walker et al., 1986) fall within the period covered by the BTB13 core. Around this same period, Northern Hemisphere glaciations began to enhance global climatic variations (Raymo, 1994). This combination of hominin evolutionary and climatic events during an interval of strong Plio-Pleistocene climatic fluctuations provides an excellent opportunity to test evolution models (e.g. deMenocal, 2004; Foley, 1994).

The main benefits for drilling cores are two-fold. On the one hand, drilled cores enable the study of a long continuous sections, not constructed from correlated short outcrop sections. A second important benefit is that the drilled sediments have been less exposed to weathering. This improves not only the quality of the paleoclimatic record 
but also the paleomagnetic record as weathering may alter the preservation of primary magnetization.

Reconstructing the stratigraphic positions of magnetic polarity reversals of known age (i.e. magnetostratigraphy) in cores usually relies on the paleomagnetic inclination, as the paleomagnetic declination cannot be established because of the rotational movement of the core segments during the drilling process. A downward inclination, in northern latitudes indicates a normal paleomagnetic direction whereas an upward inclination indicates a reversed paleomagnetic direction. However, the HSPDP sites are located at low latitudes, where the inclination of the Earth's (paleo)magnetic field is sub-horizontal, making it ineffective to use inclination for rece nstructing the magnetostratigraphy. For the HSPDP project we developec a si $t$ of custom paleomagnetic processing techniques (for details see Si r et 1 l., 2017). The first method uses the sedimentary fabric as expressed in the anisntr $\mathrm{v}_{\mathbf{1}} \mathrm{V}$ of the magnetic susceptibility (AMS), and the second uses the occurrence of $\sec ^{-12} \mathrm{y}$ viscous (paleo)magnetic component oriented in the present-day field $f_{1,1}$, rientating primary paleomagnetic directions. For this study, we use both met' ds and our results match with the ${ }^{40} \mathrm{Ar} /{ }^{39} \mathrm{Ar}$ ages from the same core (see Deino e. al. this issue for discussion).

\section{Geological setting}

The drill site (latitude $0.5540^{\circ} \mathrm{N}$, longitude $35.9375^{\circ} \mathrm{E}$ ) is located in the Baringo Basin/Tugen Hills, which s p.rt of the Central Kenya Rift Valley, west of Lake Baringo (Fig. 1). The bas1. c untains the most complete late Neogene sequence of the

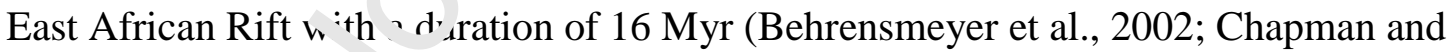
Brook, 1978; Hill, 2no') and a thickness of $\sim 3 \mathrm{~km}$ (Gilbert et al., 2010). The sediments are divided into a number of formations. The Chemeron Formation, which was first formally described by McCall et al. (1967), ranges in age from 5.3 to 1.6 Ma (Deino et al., 2006). It is exposed in the eastern foothills of a westward tilted horst block within the basin. The formation consists of lacustrine and subaerial sedimentary strata and relatively minor siliceous tuffs.

The 228 meter long core was recovered at a distance of about 20 meters from cliff exposures (Campisano et al., 2017). The cored strata are correlated to dated outcrops ranging from $\sim 2.6$ to 3.3 Ma (Cohen et al., 2016; Deino et al., this issue). The upper part contains five cyclic deep-lake diatomites correlated in outcrop to Diatomite 5 to 
Diatomite 1 from youngest to oldest (Deino et al., 2006; Kingston et al., 2007). The lower part of the core consists of fluviolacustrine deposits and floodplain paleosols (Scott et al., this issue). Full stratigraphic descriptions are reported in Scott et al. (this issue).

\section{Methods}

\subsection{Sampling of BTB13 core}

Paleomagnetic samples were collected directly after the splitting of the core at the US National Lacustrine Core Facility (LacCore) at the University if Minnesota (USA). The vertically drilled 228 meters long BTB13 core (for drilling teta ls see Cohen et al., 2016) was sampled at 543 levels for a total of 567 palec mag netic samples in regular intervals throughout the core, with an average spatial $\mathrm{rc}$. olution of around $0.41 \mathrm{~cm}$. The sample stratigraphic position was measured with $<\imath 5 \mathrm{~cm}$ precision. The orientation with respect to the top of the core was then $m, \mathrm{rr}$ ed on each sample. Samples were collected using several methods. Most $\operatorname{sam}_{\mathbf{1}}{ }^{1}$ es were extracted using an drill press equipped with a water-cooled diamor. ${ }^{\prime}$ - $\mathrm{c}$ ' ated $2.5 \mathrm{~cm}$ diameter bit. Levels too soft for drilling were sampled by gently pu. hing custom-made quartz containers, with standard paleomagnetic sampling dimensir ns (95 mm diameter, $22 \mathrm{~mm}$ length), into the sediment. Levels that were toc tra rue for drilling but not soft enough for insertion of the quartz cup containers we e carefully carved out in blocks of $2 \times 2 \mathrm{~cm}$. Some levels also had small unoriente. ${ }^{1}$ san ples collected for rock magnetic experiments. With these various techniques al lith slogies encountered in the core could be sampled. Only intervals where the cor ' was broken up as a result of the drilling process were avoided. After labelling, the samples were wrapped in laboratory-grade air-tight cellophane and stored at temperatures below $5^{\circ}$ Celsius.

\subsection{Rock magnetism}

In order to help identify the magnetic mineralogy, several rock magnetic measurements were undertaken. To quantify the characteristic behavior of the magnetic mineralogy of the individual samples during heating and cooling, thermomagnetic curves were measured in air on a modified horizontal translation-type Curie balance 
with a sensitivity of about $5 \times 10^{-9} \mathrm{Am}^{2}$ (Mullender et al., 1993) at the Paleomagnetic Laboratory Fort Hoofddijk, Utrecht University, the Netherlands. Four samples were powdered with a mortar, and weights were measured on a laboratory scale. The powder was put in a small container on a quartz rod, and the container was closed with quartz wool. The magnetic field was cycled between a minimum of $100 \mathrm{mT}$ and a maximum of $300 \mathrm{mT}$. Heating and cooling cycles (with rates of $6^{\circ}$ and $10^{\circ} \mathrm{C} / \mathrm{min}$ ) were run using cycles $20-300,200-400,300-700{ }^{\circ} \mathrm{C}$ (Fig. 2a).

Hysteresis curves of 50 samples (see Supplemental Table S1) were measured on a vibrating sample magnetometer (VSM, MicroMag Model 3900; Princeton Measurements). The hysteresis parameters (the saturation rer.⿲丿 nence $\mathrm{M}_{\mathrm{sr}}$, saturation magnetization $M_{s}$, the remanent coercive force $H_{c r}$ and he ( rdin ary coercive force $H_{c}$ ) give information about the domain state or paleomagne ic st ıbility of magnetic minerals in the samples (Dunlop et al., 2002a). A correction for $r$ aramagnetic contribution was applied to the hysteresis curves and the hysteresis $\ldots$.r. neters were determined. The ration of the hysteresis parameters $\left(\mathrm{M}_{\mathrm{sr}} / \mathrm{M}_{\mathrm{s}}\right)$ r e, z plotted against $\left(\mathrm{H}_{\mathrm{cr}} / \mathrm{H}_{\mathrm{c}}\right)$ in a Day plot (Day et al., 1977) and using the approach c $c^{\dagger}$ Duntop (2002a,b), were interpreted in terms of (mixtures of) superparamagn tis (SP), single domain (SD), pseudo single domain (PSD) and multi domain (1. ${ }^{\top} \mathrm{D}$ : Fig 3b).

Furthermore, 26 samples $\boldsymbol{r} 1,2 \mathrm{v}$ ) were subjected to an IRM acquisition (using a $2 \mathrm{G}$ pulse magnetizer, $2 \mathrm{G}$ Ente pires) up to $1 \mathrm{~T}$, then given an IRM of $0.3 \mathrm{~T}$ in the antiparallel direction to sepa ate nigher from lower coercivities, and then a stepwise thermal (TH) demagneti: atio . of these separated components of the natural remanent magnetization (NRM) in 12 temperature steps in order to further help mineral identification by mean. of unblocking temperatures (Heller, 1977).

\subsection{Demagnetization and ChRM directions}

Stepwise progressive TH demagnetization of the NRM was performed for 262 samples up to a maximum of $600^{\circ}$ Celsius, in 12 or 14 temperature steps using an ASC thermal demagnetizer (residual field $<20 \mathrm{nT}$ ) at the Fort Hoofddijk Paleomagnetic Laboratory (Utrecht University, the Netherlands) and the Centro Nacional de Investigación sobre la Evolución Humana (CENIEH) in Burgos (Spain). After each step the remaining NRM was measured with a 2 G DC-SQUID cryogenic magnetometer. NRM intensities were typically several orders of magnitude higher than the instrument 
sensitivity $\left(\sim 3 \times 10^{-12} \mathrm{Am}^{2}\right)$. During the demagnetization process, the specimens were kept in a shielded environment. No notable differences of results between the two laboratories have been observed. Stepwise progressive Alternating Field (AF) demagnetization was done for two pilot samples up to a maximum of $100 \mathrm{mT}$, in 16 alternating field steps using the integrated AF demagnetizer of the DC-SQUID magnetometer of the CENIEH. However, these resulted in unclear component separation compared to thermal demagnetizations such that thermal demagnetization was exclusively used for further samples. After a pilot study of 100 samples carefully demagnetized with numerous temperature steps, further selected samples were processed with optimal demagnetization steps.

The demagnetization results were interpreted in ter as o components to identify the ChRM directions using Paleomagnetism.org, an onl ne 1 lulti-platform open source environment for paleomagnetic data analysis (Koyman et al., 2016) providing a suite of techniques to statistically interpret the results (C. ser et al., 1980; Deenen et al., 2011; Fisher, 1953; Kirschvink, 1980; Zijderveld, $1^{r} \mathbf{0}^{\top}$ ). A minimum of four consecutive steps was considered to define ChRM direc ions.

\subsection{Anisotropy of magnetic sus aptibility (AMS)}

The Anisotropy of Magneti,$\therefore$ : sreptibility (AMS) was measured for 210 samples (see Supplemental Table S2) v 11. aı MFK1-FA Kappa Bridge before demagnetization. AMS is useful for determin: ' $\mathrm{g}$ a úominant orientation of magnetic minerals within a sample. In sedimentary racks AMS can be used to determine the tectonic and/or sedimentary fabric po ent 1 lly preserved in the rocks (e.g. Hrouda, 1982). An ellipsoid describes the AMS ge metrically with defined minimum $\left(\mathrm{k}_{\min }\right)$, intermediate $\left(\mathrm{k}_{\mathrm{int}}\right)$, and maximum $\left(\mathrm{k}_{\max }\right)$ axes. During deposition and compaction, sedimentary rocks generally acquire an oblate 'sedimentary fabric', which can be recognized by having $\mathrm{k}_{\text {min }}$ directions clustering perpendicular to the bedding plane. The other axes generally are (sub) parallel to the bedding plane with no preferred orientation unless affected by tectonic or depositional processes. 


\subsection{Reorientation of ChRM directions}

Due to the rotational movement of the drilling, the azimuthal orientation of the HSPDP cores are lost. Additionally, the low latitudes of core locations hampered the use of the inclination of the paleomagnetic direction as a proxy for paleomagnetic polarity. To overcome this challenge, we have used two independent methods to reorientate the BTB13 and other HSPDP cores. First, the AMS principle tensor directions preserve the orientation of the sedimentary fabric and thus enables the bedding dip to be estimated (see Sier et. al., 2017 for more details). To be effective, a bedding dip of at least 15 degrees is required and the dip direction should be known. This can be achieved by drilling dipping strata or by drilling at an angle or both. If the dip direction is unknown or has large variations in direction, this methor $a_{1 \ldots} \mathrm{st}$ be used for identifying

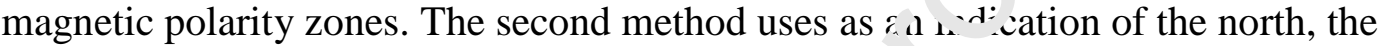
possible occurrence of a secondary present-day ov $\mathrm{rp}_{\mathrm{l}} \mathrm{nl}$ on top of the ChRM direction (Fuller, 1969). This method requires the occurrense o. this secondary overprint, the preservation of the original ChRM, and that $1 \mathrm{~J}^{+} \mathrm{a} \cdot$ omponents can be distinguished from another. In practice, not all samples $m_{\lrcorner}{ }^{\prime}$ he $e^{\circ}$ preconditions (see below).

\section{Results}

\subsection{Anisotropy of m: 7y.-etic susceptibility (AMS)}

A total of 240 1v: 5 measurements of the BTB13 core paleomagnetic samples were processed ( $\operatorname{Sup}_{r}{ }^{1}$ emental Table S2), of which 32 outliers were ignored because of indications of measurement errors during the measurement process $(\mathrm{L}, \mathrm{F}, \mathrm{P}$ values of 1,000). The remaining 208 are plotted in Figure 4. The stereographic projection show a typical distribution for a sedimentary fabric. The $\mathrm{k}_{\min }$ axes cluster around the vertical, and the $\mathrm{K}_{\max }$ and $\mathrm{K}_{\mathrm{int}}$ distributed along the horizontal. The anisotropy $(\mathrm{P})$ of most samples is fully expressed by foliations $(\mathrm{F})$ in the $0-2 \%$ range. This foliation is generally higher (average $1.4 \%$ ) and more variable from 5.25 to 130 meters below surface (mbs) compared to below $130 \mathrm{mbs}$ (average $0.6 \%$ ), with notable peaks above $2 \%$ and up to $7 \%$ at $180 \mathrm{mbs}, 120 \mathrm{mbs}, 110 \mathrm{mbs}$, and $90 \mathrm{mbs}$. From $25 \mathrm{mbs}$ to $50 \mathrm{mbs}$, there is a progressive increase in $\mathrm{K}_{\min }$ inclinations from ca. $45^{\circ}$ to $80^{\circ}$, which 
corresponds to a shallowing of bedding dip from $45^{\circ}$ to $10^{\circ}$. Generally, high $\mathrm{K}_{\min }$ inclinations between $50 \mathrm{mbs}$ and $210 \mathrm{mbs}$, indicate continuance of a consistent dip. Exceptions are short intervals at $145 \mathrm{mbs}, 160 \mathrm{mbs}$, and $195 \mathrm{mbs}$. Below ca. $210 \mathrm{mbs}$, lower $\mathrm{K}_{\min }$ inclinations point towards increased bedding dip. Note that occasional spuriously low $\mathrm{K}_{\min }$ inclinations cannot relate to bedding dip changes, but rather to variable rock magnetic properties caused by lithological variations or strata disturbed by faulting.

The results of the AMS reveal the sections of the core with flat-lying bedding orientations are not suitable to infer normal and reversed polarities. The cause of this is firstly that the orientation of the magnetic directions will be i... istinguishable from the bedding dip. In addition, the declination of the $\mathrm{K}_{\min }$ cannot be $\mathrm{\imath}$ sed to estimate the dip direction as previously done to recover the orientation c $f$ tht WKT14 core (Sier et al., 2017) and ultimately recover the paleomagnetic polar 1 ; Even in the more steeply dipping portions (5.25-50 mbs and below $210 \mathrm{mbs}$, "'mparing $\mathrm{K}_{\min }$ inclinations with ChRM declinations yields unfortunately very vo iable declinations with no consistent pattern from which to infer paleomagnetic ${ }_{i}$ olanty (Supplemental Table S2). This may be attributed to variability in the AMr rer alts, but also the variability in the ChRM directions that may include mixed ${ }_{\mathbf{r}}$-rimary and secondary directions (see below).

\subsection{Demagnetization kisults}

A total of 543 BTB1's core levels have been sampled for paleomagnetic analyses of which 264 samples wel : thermally or alternating field demagnetized, 257 samples were of sufficient quai ${ }^{+} y$ to yield interpretable directions (see Supplemental Table S3). The Zijderveld diagrams (Fig. 5) show a low-temperature (LT) component from $20^{\circ} \mathrm{C}$ to $150-200^{\circ} \mathrm{C}$ occasional extending to $250^{\circ} \mathrm{C}$. The high-temperature (HT) component follows the $\mathrm{LT}$ from $175-250^{\circ} \mathrm{C}$ to $550-600^{\circ} \mathrm{C}$. For a large majority of the samples, demagnetization was completed above $550^{\circ} \mathrm{C}$ with a maximum of $600^{\circ} \mathrm{C}$, but in some cases, samples were fully demagnetized by $350^{\circ} \mathrm{C}$. The relationship between the LT and HT can be divided into two groups. One group has parallel LT-HT components whereas a second group has LT components, which are antiparallel or at a high angle to the HT component. This distribution is typical of an LT component representing a modern secondary overprint exclusively in a normal polarity orientation and a HT 
component with a primary magnetization of normal or reversed polarities. This was often observed in previous paleomagnetic studies in the volcanic-rich East African Rift (e.g. Deino et al., 2002; Dupont-Nivet et al., 2008).

\subsection{Rock magnetic results}

Rock magnetic properties were explored to help identify the nature of the observed LT and HT components so that their secondary and primary origins can be better assessed. Previous paleomagnetic studies from the surrounding outcrop section of the same stratigraphy have indicated a dominance of Ti-rich titanomagnetite in the magnetic carriers (Deino et al., 2006). This is often the case 1. the rift valley, which is dominated by volcanic environments and often leads to we 1 pr served primary magnetizations. Pervasive secondary overprints carried by li ss stable Ti-rich magnetite in larger multi-domain grains are usually observed wiı. normal polarity present-day field orientation (e.g. Dupont-Nivet et al., 2008; Jo $r d r$,ns et al., 2011; Sier et al., 2017). However, the properties may be different in th. ore material, which may be less affected by post-depositional alteration cor narcu to outcrops.

NRM intensities are generally 'ig'^ (Supplemental Table S2) suggesting, along with high bulk susceptibility value: (Suppıemental Table S3), that magnetite-like (ferromagnetic) minerals are imp, $\mathrm{rt}$. nt contributors to the magnetization.

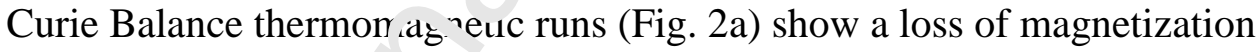
mostly between $200^{\circ} \mathrm{C}$ and $590^{\circ} \mathrm{C}$ with the destruction of the magnetic phase and no creation of new magnetic pha ses. This is generally consistent with the thermomagnetic behavior of magnetite but zontrary to the expected behavior for iron sulfides that would transform into magnel' $\mathrm{e}$ in that temperature range.

The IRM acquisition and thermal demagnetizations (Fig. 2b) show two groups of higher and lower coercivities respectively, which demagnetize following the two components $\mathrm{LT}\left(0-150^{\circ} \mathrm{C}\right)$ and $\mathrm{HT}\left(150-550^{\circ} \mathrm{C}\right)$ similar to most of the thermal demagnetizations of the core (see above). In both high and low coercivity groups, the LT component shows a marked decrease ca. $125-150^{\circ} \mathrm{C}$ and the HT component is mostly decreasing steadily from $150^{\circ} \mathrm{C}$ to $550^{\circ} \mathrm{C}$. Sometimes a marked decrease around $500-600^{\circ} \mathrm{C}$ can be observed in the high coercivity group.

Hysteresis curves (Fig. 3a) can be separated into two groups. One group (BTB13-1A-43Q-1-102 and BTB13-7Q-2-58 in Fig. 3a) shows no indication for high 
coercivity minerals. The second group show wasp-waisted hysteresis curves (BTB131A-50Q-3-2/68Q-2-14) indicating the presence of higher coercive minerals or a mixture of lower and higher coercivities (Tauxe et al., 1996). These behaviors correspond well with the results of the IRM demagnetization presented above. Saturation generally reached near $200 \mathrm{mT}$ may correspond to magnetite or an iron sulfide such as greigite but indicate no influence of the high coercivity goethite or hematite minerals in those samples (e.g. Roberts et al., 2011; Vasiliev et al., 2007). $\mathrm{H}_{\mathrm{c}}$ values are around 10 to 20 $\mathrm{mT}$ with $\mathrm{H}_{\mathrm{cr}}$ values between 25 and $60 \mathrm{mT}$. These values are not diagnostic and may correspond to magnetic minerals such as (titano)magnetite, fine-grained maghemite or iron sulphide such as greigite, and pyrrhotite (Özdemir and Du nlop, 1997; Peters and Dekkers, 2003). The Day plot, a plot of ratios $\mathrm{M}_{\mathrm{sr}} / \mathrm{M}_{\mathrm{s}}$ and $\mathrm{I}_{\mathrm{cr}} / \mathrm{F}$, shows that nearly all values fall within the SD domain with a group near or c 1 th SP boundary (Fig. 3b). These SP values may correspond to very fine-grained 1. agnetic minerals from detrital sediment material and/or be produced in situ by pos ${ }_{-}-$- positional processes such as diagenesis and pedogenesis (Dunlop, 2002a, ?vi2b).

In summary, the rock magnetic proresties of investigated samples, along with the demagnetizations and AMS result. $a^{2} \pm$ not distinguishable from properties of nearby outcrop results that have be $\backsim$ previously shown to be dominated by magnetite with variable Ti content and grair -s - typical of volcanic-rich sediments of the East African rift. The dominance of a ${ }^{\prime}$ w coercivity component demagnetizing mainly in the $200-550^{\circ} \mathrm{C}$ range is consiste it with the presence of titanomagnetite with significant $\mathrm{Ti}$ content. The phase of hi her sercivity demagnetizing below $200^{\circ} \mathrm{C}$ is consistent with goethite, however it is not suggested by hysteresis curves and may instead relate to high Ti titanomagnetite. Th h higher coercivity fraction demagnetized between $500-600^{\circ} \mathrm{C}$ remains enigmatic. It may relate to very fine-grained hematite that does not appear on the hysteresis dominated by magnetite. Rock magnetic data of the BTB13 core investigated here are not distinguishable from a dominant titanomagnetite behavior that was identified in the outcrop as being the primary carrier of magnetization (Deino et al., 2002, 2006). This supports the assumption that the LT component may be interpreted as a secondary normal overprint on a primary HT component as observed in previous outcrop paleomagnetic results. 


\subsection{Identification of the ChRM directions and polarities}

As mentioned above (Section 4.1), re-orientation of samples by means of AMS (Sier et al., 2017) proved inefficient because of mostly horizontal bedding orientation throughout the core. Changes in dip of the bedding was also observed during the sampling when stratification was expressed in the sediment, showing relatively steep bedding in the upper 20 to 30 meters to nearly flat lying in the middle part with occasional steep intervals, especially in the lowermost 20 to 30 meters of the core. However, these observations only provide an approximate and patchy record of bedding dip. These variations were not related to the placement of th $>$ core split at different orientations but to actual changes in the bedding orientation $T_{h}$ is confirmed by the AMS measurements of 210 samples throughout the core (ce supplemental Table S2), indicating a significant flattening of the bedding belor/ $?^{n}$. bs and occasional local variations at $145 \mathrm{mbs}, 160 \mathrm{mbs}, 195 \mathrm{mbs}$, and gen rai' velow $210 \mathrm{mbs}$.

For re-orienting the samples, we therefore 'ise ' only the normal overprints. As mentioned above (Section 4.3) two groups of d/m agnetization diagrams can be identified. We first have interpreted th $f$ z. $\mathrm{vu}_{\mathrm{r}}$ showing antiparallel LT and HT directions as having a primary reversed : T direction. Directions were calculated from LT as well as HT components using : ${ }^{\prime}$ e fits. To re-orient those samples, the HT directions were simply rotated the $\mathrm{s}$ sunt necessary to rotate the LT component towards the north (e.g. LT wii: $27 \mathrm{v}^{\circ}$ needs to be rotated $90^{\circ}$, the corresponding HT direction has also $90^{\circ}$ addc ${ }^{\top}$, s.e also Supplemental Table S3). In a few samples, a reversed direction is clear, ${ }^{i}{ }^{i}$.dicated by a high angle between the HT component and the LT component. $\mathrm{H}_{\mathrm{G}}$ ve; er, HT and LT are not antiparallel because of an LT component less stror ${ }^{1} y$ expressed and overlapping with the HT component. For these few samples a great circle was fit to the points over the overlapping components. The direction of the LT component was assigned to the point on the great circle closest to the antiparallel of the HT component direction, similar to the great circle method developed by McFadden and McElhinny (1988) for overlapping directions (see Supplemental Table 4). These methods enabled identification and subsequent reorientation of reversed polarity samples.

Identifying normal polarity directions by this method is generally more challenging than identifying reversed polarity direction, because normal overprints are not always expressed (i.e. originally reversed samples without a normal overprint 
cannot be distinguished from originally normal directions with or without a normal overprint). Nevertheless, we initially interpreted all samples with parallel LT and HT directions as of normal polarity and re-oriented them by rotating the LT towards the North. When plotted stratigraphically (Fig. 6), this resulted in zones of exclusively normal polarity direction and zones with mixed normal and reversed polarity directions. This shows that originally reversed directions have been interpreted as normal directions that are now mixed within reversed polarity zones. Based on this dataset our best approximation for identifying polarity reversals was to position them at the boundary between exclusively normal zones and mixed reversed and normal zones. The first identified reversed sample after an exclusively normal $\mathrm{zu}_{1} \cdot{ }^{\circ}$ therefore defines the boundary. Based on this method, we identified four reversi $1 \mathrm{~s}$ p ecisely at $19.79 \pm 0.1$ mbs, $125.86 \pm 0.3 \mathrm{mbs}, 154.64 \pm 0.145 \mathrm{mbs}$ and $199.625 \pm 1.245 \mathrm{mbs}$, respectively, defining two normal and three reversed zones (Fig. 6). Iowever, it is possible that the boundary is located slightly into the normal zone $b_{c^{* a}}$ se of potential unidentified reversed directions in this normal zone. Althe dy i a few reversed samples may have been missed over the reversals, we argue th. 't large errors in the positioning of paleomagnetic reversals are unlikely ive.1 that the core has been sampled at high

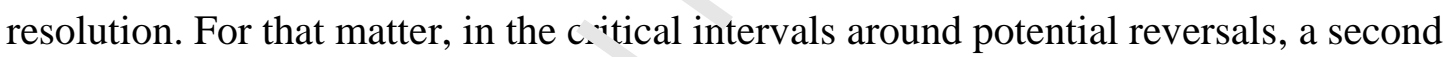
set of closely spaced samples wer $:$ alyzed to define the reversal interval as tightly as possible.

\section{Discussion}

Re-orientatic $\mathbf{o}^{\prime} \mathbf{r n}^{\prime}$ atory drilled cores near the equator for magnetostratigraphic purposes is a major $\mathrm{ch}$ : llenge. Cores drilled at higher latitudes have their magnetostratigraphy determined on the basis of changes in paleomagnetic inclination. A change from a downwards to upwards inclination (and vice versa) indicates a reversal. However, near the equator the inclination of the Earth's magnetic field is near zero and changes in inclinations are most likely the results of secular variation. As a result, the determination of the magnetic polarity in cores near the equator on the basis of inclination is not possible. For the HSPDP project we have used two methods to circumvent this issue (for more details see Sier et al, 2017). The first method based on AMS requires a constant bedding dip throughout the core of at least $15^{\circ}$ in order to separate the bedding signal from the intrinsic noise in the AMS data. A significant 
eastward dip of the strata was present near outcrops at the BTB13 drill site (Deino et al., 2006). For this reason, the BTB13 core was drilled straight down, unlike the Turkana core, as no added angle was thought to be needed for the AMS reorientation method (see also Sier et al., 2017). However, during the splitting and sampling of the core it was observed that the bedding dip had some variation (Cohen et al., 2016) and it was confirmed by the AMS data to be mostly flat lying below $50 \mathrm{mbs}$ (Fig. 4 and Supplemental Table S2). As a result, the reorientation of the BTB13 core by means of the AMS reorientation method was not successful as it failed to identify zones of magnetic polarity. The procedure was unsuccessful even in portions of the core with sufficient dip to apply this method, especially in the upper 50 neters. This is explained by the variability in the quality of the AMS directions that nay relate to variations in lithology and rock magnetic properties. It is also relatec to $t$ te high variability in ChRM directions due to the presence of overlapping secondar y overprints sometimes fully erasing the primary component. This underlines that th ${ }^{2}$ method requires high quality ChRM and AMS data in addition to a good cr itt ol of bedding orientations.

The second method, based on the dirstion a secondary paleomagnetic component, however, was successfull, ar plied to the BTB13 core. This method was shown to be applicable because of :he occurrence of a secondary low-temperature

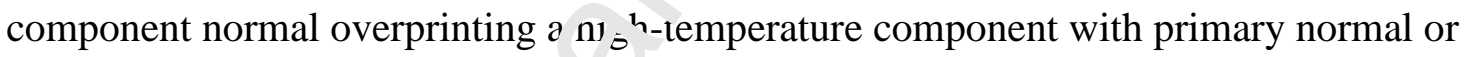
reverse directions. This patterr o ${ }^{2}$ erved in the BTB13 core Zijderveld diagrams (see Fig. 5) could be confirmed $i$.' sinilar paleomagnetic components in outcrops of the same stratigraphic interv ls ( 冫eino et al., 2002, 2006). Furthermore, the rock magnetic behaviors explored in the ore samples were shown to be very similar to the outcrop indicating magnetite $\mathrm{w}$ th variable Ti content as the main carrier of the LT and HT components. This validated this assumption of a normal LT overprint on a primary HT ChRM. When present, the two (unoriented) directions could be separated in the majority of the samples. However, in some samples, two directions resulting from overlapping directions were present but lacked a clear separation of components. We managed to obtain and separate LT and HT directions in these samples by using an adapted great circle analysis (see Section 4.4 and Fig. 5). ChRM directions from HT components were re-orientated by rotating the LT declinations towards the north assuming they are normal overprints. Plotting the resulting directions clearly identify five paleomagnetic polarity zones with reversed zones showing mixed reversed and 
normal (Fig. 6). To estimate the reversal position, we used the first reversed sample after an exclusively normal zone. To confirm reversals, we we decreased samples spacing in critical intervals.

With the help of the radiometric ages obtained from the same core (see Deino et al., this issue), we could identify the paleomagnetic reversals at the zone boundaries. A unique correlation to known reversals could be readily achieved based on the other 29 control points that were used to develop a Bayesian chronostratigraphic model for the BTB13 core. These include ${ }^{40} \mathrm{Ar} /{ }^{39} \mathrm{Ar}$ dating of tuffs obtained directly from samples from the core, but also by correlating dated outcrops tuffs to the core based on geochemical correlation identification (Garello et al., this issu) In addition, extra control points were obtained from ages of Diatomites 1 thr ugg 5 based on outcrop calibration by ${ }^{40} \mathrm{Ar} /{ }^{39} \mathrm{Ar}$-dating of intercalated tuffs (De no $\epsilon$ : al., 2006; Kingston et al., 2007).

The top reversal can be directly correlated to ${ }^{\text {th }} f$ nearest outcrop $(\sim 20 \mathrm{~m})$ where the Matuyama-Gauss reversal has been identi ${ }^{5}$. 1 within Diatomite 4 and several core to outcrop correlations of ${ }^{40} \mathrm{Ar} /{ }^{39} \mathrm{Ar}$ dates (De: vo et al., 2006; 2.61 Ma or the point marked 'A' on figure 6 in Deino et al., th's issue). Finding the Matuyama-Gauss reversal within the same diatomite $\eta \eta$ the В ГВ13 core supports the validity of our paleomagnetic methods. The thre $-\mathrm{r}$-rersals observed below the Matuyama-Gauss are interpreted to correlate to the Can-s-Kaena, Kaena-Gauss and Gauss-Mammoth. Reversal ages are based on $\iota$ e geomagnetic polarity time scale (GPTS 2012; Gradstein et al., 2012) except for th a Miruyama-Gauss transition that has been shown to be slightly older (Deino $t$ al. 2006). Instead, an age of 2.608 Ma was used based on the median of the GPTS1 $\angle$ marine stack (Lisiecki and Raymo, 2005), and evidence from the Boring Volcanic field (Hagstrum et al., 2017). For a detailed discussion on that matter see Deino et al. (this issue). The top of the Mammoth chron boundary estimated at 199 $\pm 0.245 \mathrm{mbs}$ is also well constrained near $\sim 184-202 \mathrm{mbs}$ to within $\sim 3.18-3.22 \mathrm{Ma}$ (see age control points $\mathrm{G}$ on figure 6 of Deino et al., this issue), by core and outcrop ${ }^{40} \mathrm{Ar} /{ }^{39} \mathrm{Ar}$ ages. However, between $101 \mathrm{mbs}$ and $184 \mathrm{mbs}$ (C and F on fig. 6 of Deino et al., this issue) the age model is constrained mainly by paleomagnetic reversals and relatively imprecise ${ }^{40} \mathrm{Ar} /{ }^{39} \mathrm{Ar}$ ages from the core. In this section, our methods to determine the reversal positions (see Section 4.4 above) allows for the upper reversal of the reversed Kaena subchron to be higher than indicated, and the lower reversal to be 
lower. Interestingly, placing the lower 3.116 Ma Kaena reversal (APTS12 age) lower in the core than indicated $(154.6 \mathrm{mbs})$ would fit better with provided ${ }^{40} \mathrm{Ar} /{ }^{39} \mathrm{Ar}$ age near that interval (159.4 mbs; $3.089 \pm 0.026 \mathrm{Ma})$. In any case, sediment accumulation rates in the interval including the Kaena (B-G; 2.72 to 3.22 Ma, Deino et al., this issue) do not vary drastically, suggesting the age model is robust.

Throughout the core, the resulting age model reveals three main intervals of accumulation rates, from relatively fast rates from 3.2-2.9 Ma to a slower accumulation rates down from 2.9-2.7 Ma and higher rates from 2.7-2.6 Ma (Deino et al., this issue). Within the control points and in accordance to these accumulation rates, alternatives to the proposed correlations of observed polarity reversals are vir 'rally impossible. Within the upper part of the Gauss we have identified two isolated revt rsed samples at 66.52 mbs (2.70 Ma) and $91.52 \mathrm{mbs}(2.82 \mathrm{Ma})$, which could i ndic te paleomagnetic excursions, but this remains speculative as we are dealı. $\mathrm{g}$, with single samples and no excursion has been previously identified in the con ${ }^{\prime} \mathrm{d}_{\digamma}$ ied time interval.

\section{Conclusions}

We have analysed a total of 264 p reomagnetic samples and our results identify four paleomagnetic reversals. The Mi-tuyama-Gauss $(2.602 \pm 0.013 \mathrm{Ma})$, the upper Kaena $(3.032 \pm 0.015 \mathrm{Ma})$, the lo $\mathrm{N}$ r saena $(3.116 \pm 0.015 \mathrm{Ma})$, and the upper Mammoth $(3.207 \pm 0.015 \mathrm{Ma}$, Thuse four reversals serve as important inputs for the multidisciplinary high-resclui ${ }^{1}$ ' n Bayesian chronostratigraphic model of the BTB13 core (Deino et al., this issun) Our rock-magnetic results indicate that the magnetic properties of the rt nat. $^{{ }^{n^{+}}+}$magnetizations in the core are similar as in the outcrop with a normal polarity second ary low-temperature component overprinting a primary normal and reverse high-temperature component carried mostly by titanomagnetite. For recovering the polarity zones of the BTB13 core, we have used two independent methods; the first makes use of the preserved AMS sedimentary fabric, whereas the second makes use of either parallel or antiparallel secondary overprints. Because of the near flat-lying orientation of strata in most of the BTB13 core, and the variability in AMS and ChRM direction, the AMS sedimentary fabric method could not be applied successfully to this specific core. However, the secondary overprint method gave clear magnetozones with opposite directions, thus enabling us to identify four reversals. 
The following are the supplementary data related to this article.

Supplemental Table S1: Hysteresis properties taken from paramagnetic corrected hysteresis curves. Sample ID, Level: stratigraphic level in metres below surface (mbs), relevant hysteresis parameters: saturation magnetization $\mathrm{M}_{\mathrm{sr}}$, magnetization $\mathrm{M}_{\mathrm{s}}$, remanent coercive force $H_{c r}$, coercive force $H_{c}$, and their ratios $M_{s r} / M_{s} H_{c r} / H_{c}$, Range: PSD pseudo single domain.

Supplemental Table S2: AMS, Sample ID, Level: stratigraphic level in mbs, Km (mean susceptibility), L (lineation), F (foliation), P (anisotropy degree), Pj (corrected anisotropy degree following Jelinek, 1981), T (shape parameter; oblate shape for $0<\mathrm{T}$ $\leq 1$, prolate shape for $-1 \leq \mathrm{T}<0$; Tarling and Hrouda, 1993) $\mathbf{K}^{-1} \mathrm{dec}, \mathrm{K} 1 \mathrm{inc}, \mathrm{K} 2 \mathrm{dec}$, K2inc, K3dec, K3inc (declination and inclination of the marim um, intermediate and minimum axes of the anisotropy tensor); K11, K22, K3: $\mathrm{K} .2, \mathrm{~K} 23, \mathrm{~K} 13$ (the six tensor elements).

Supplemental Table S3: AF and TH palaeomagneli results. Sample ID\#: sample identification; Level: stratigraphic level in $\mathrm{m} r \mathrm{tr}, \mathrm{s}$ below surface (mbs); Dec HC/HT: declination of high-coercivity component (1.C)/ high-temperature component (HTC) in

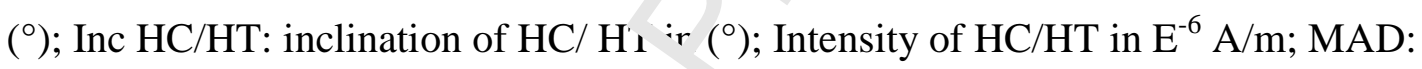
Maximum Angular Deviation; Min s tep HC/HT: minimum demagnetization step in mT $\left(^{\circ}\right)$ of HCC/HTC; Max Step HC/I T. s aximum demagnetization step in mT and $\left(^{\circ}\right)$ of HCC/HTC; Dec LC/LT: declinatı n of low coercivity component/ low-temperature component (LC/LT) in degrt: $:$, this is the component reoriented towards the north; Inc LC/LT: inclination of LC,' T in degrees; Min Step LT; Max Step LT; re-orientated Dec $\mathrm{HC} / \mathrm{HT}$.

Supplemental Table $\$$ 4: Great Circle (GC) palaeomagnetic results. Sample ID\#: sample identification; Level: stratigraphic level in metres below surface (mbs); Dec GC: declination of GC in degrees; Inc GC: inclination of GC in degrees; Intensity: intensity of calculated GC in $\mathrm{E}^{-6} \mathrm{~A} / \mathrm{m}$; MAD: Maximum Angular Deviation; Min Step GC: minimum step of GC in $\mathrm{mT}$ and $\left(^{\circ}\right)$; Max Step GC: maximum step of GC in mT and $\left(^{\circ}\right)$

\section{Acknowledgements}

Acquisition of the BTB13 drill core and sampling was funded by the International Continental Drilling Program and US-NSF grants (EAR-1123942, BCS- 
1241790, EAR-1338553, and EAR-1322017). MJS was funded by Netherlands Organisation for Scientific Research grants NWO-ALW 823.01.003 and is currently funded as a Juan de la Cierva post-doctoral fellow. GDN acknowledges funding from Marie Curie CIG FP7 grant 294282 “HIRESDAT”. We thank the Kenyan National Council for Science and Technology and Kenyan Ministry of Mines for providing research and export permits, and the National Environmental Management Authority of Kenya for providing environmental permits for the drilling in the Tugen Hills. We also would like to acknowledge DOSECC Exploration Services for drilling supervision, the team of the US National Lacustrine Core Facility (LacCore) for help during drilling and sampling. Finally, we would like to thank the two anonymous aviewers whose comments greatly improved this paper. This is publication vum jer XX of the Hominin Sites and Paleolakes Drilling Project.

\section{Declaration of interests}

The authors declare that they have no known competing . 'nancial interests or personal relationships that could have appeared to influer ie che work reported in this paper.

The authors declare the following financial int e ests/personal relationships which may be considered as potential competing interf sts:

\section{References}

Behrensmeyer, A.K., 2006. Clin. te Cnange and Human Evolution. Science. 311, 476-478. https://doi.org/10.1126/^c1c.ce.1116051

Behrensmeyer, A.K., Deino, 4.'.., Hill, A., Kingston, J.D., Saunders, J.J., 2002. Geology and geochronology of he $\mathrm{n}$ iddle Miocene Kipsaramon site complex, Muruyur Beds, Tugen Hills, Kenya. J. Huı 1. Evol. 42, 11-38. https://doi.org/10.1006/JHEV.2001.0519

Braun, D.R., Aldeias, V., Archer, W., Arrowsmith, J.R., Baraki, N., Campisano, C.J., Deino, A.L., DiMaggio, E.N., Dupont-Nivet, G., Engda, B., Feary, D.A., Garello, D.I., Kerfelew, Z., McPherron, S.P., Patterson, D.B., Reeves, J.S., Thompson, J.C., Reed, K.E., 2019. Earliest known Oldowan artifacts at $>2.58$ Ma from Ledi-Geraru, Ethiopia, highlight early technological diversity. Proc. Natl. Acad. Sci. 201820177.

https://doi.org/10.1073/pnas.1820177116

Campisano, C.J., Cohen, A.S., J. Ramon Arrowsmith, A.A., Behrensmeyer, A.K., Brown, E.T., Deino, A.L., Deocampo, D.M., Feibel, C.S., Kingston, J.D., Lamb, H.F., Lowenstein, T.K., Noren, A., Olago, D.O., Owen, R.B., Pelletier, J.D., Potts, R., Reed, K.E., Robin W. Renaut, James M. Russell, J.L.R., Schäbitz, F., Stone, J.R., Trauth, M.H., Wynn, J.G., 
2017. The Hominin Sites and Paleolakes Drilling Project: High-Resolution Paleoclimate Records from the East African Rift System and Their Implications for Understanding the Environmental Context of Hominin Evolution. PaleoAnthropology 1-43.

Chapman, G.R., Brook, M., 1978. Chronostratigraphy of the Baringo Basin, Kenya., in: Bishop, W.W. (Ed.), Geological Background to Fossil Man. Scottish Academic Press, Edinburgh, pp. 207-223.

Cohen, A., Campisano, C., Arrowsmith, R., Asrat, A., Behrensmeyer, A.K., Deino, A., Feibel, C., Hill, A., Johnson, R., Kingston, J., Lamb, H., Lowenstein, T., Noren, A., Olago, D., Owen, R.B., Potts, R., Reed, K., Renaut, R., Schäbitz, F., Tiercelin, J.J.J.-J., Trauth, M.H., Wynn, J., Ivory, S., Brady, K., O\&apos;Grady, R., Rodysill, J., Githiri, J., Russell, J., Foerster, V., Dommain, R., Rucina, S., Deocampo, D.., Russelı, I., Billingsley, A., Beck, C., Dorenbeck, G., Dullo, L., Feary, D., Garello, D., Grom o, R , Johnson, T., Junginger, A., Karanja, M., Kimburi, E., Mbuthia, A., McCartney, T., । IcNulty, E., Muiruri, V., Nambiro, E., Negash, E.W., Njagi, D., Wilson, J.N., 1 ' bideaux, N., Raub, T., Sier, M.J., Smith, P., Urban, J., Warren, M., Yadeta, M., Yo ‘ C. Zinaye, B., O’Grady, R., Rodysill, J., Githiri, J., Russell, J., Foerster, V., Dommain, R., Kucina, S., Deocampo, D.., Russell, J., Billingsley, A., Beck, C., Dorenbeck, C., 'ul' o, L., Feary, D., Garello, D., Gromig, R., Johnson, T., Junginger, A., Karanja, A., Kiı.buri, E., Mbuthia, A., McCartney, T., McNulty, E., Muiruri, V., Nambiro, E., Negash, E.W., Njagi, D., Wilson, J.N., Rabideaux, N., Raub, T., Sier, M.J., Smith, P., 'Trban, J., Warren, M., Yadeta, M., Yost, C., Zinaye, B., 2016. The Hominin Sites ai d Pc itolakes Drilling Project: inferring the environmental context of human evolution fron. eastern African rift lake deposits. Sci. Drill. 21, 1-16. https://doi.org/10.5194/su ग1-1-2016

Creer, K., Readman, P., Ja \bs, A., 1980. Palaeomagnetic and palaeontological dating of a section at Gioia T: uro, Italy: Identification of the Blake event. Earth Planet. Sci. Lett. 50, 289-300.

Day, R., Fuller, M., Scnmidt, V.A., 1977. Hysteresis properties of titanomagnetites: Grain-size and compositional dependence. Phys. Earth Planet. Inter. 13, 260-267. https://doi.org/10.1016/0031-9201(77)90108-X

Deenen, M.H.L., Langereis, C.G., van Hinsbergen, D.J.J., Biggin, A.J., 2011. Geomagnetic secular variation and the statistics of palaeomagnetic directions. Geophys. J. Int. 186, 509520. https://doi.org/10.1093/gji/ggu021

Deino, A.L., King, J.W., Glen, J.M., Edgar, R.K., Hill, A., 2006. Precessional forcing of lacustrine sedimentation in the late Cenozoic Chemeron Basin, Central Kenya Rift, and calibration of the Gauss/Matuyama boundary. Earth Planet. Sci. Lett. 247, 41-60. https://doi.org/10.1016/j.eps1.2006.04.009 
Deino, A.L., Sier, M.J., Garello, D.I., Keller, B., Kingson, J.D., Scott, J.J., Dupont-Nivet, G., Cohen, A.S., this issue. Chronostratigraphy of the Baringo-Tugen-Barsemoi (HSPDPBTB13-1A) core - 40Ar/39Ar dating, magnetostratigraphy, tephrostratigraphy, sequence stratigraphy and Bayesian age modeling. In: Scott, J.J., Stone, J.R., Sier, M.J., Kingston, J.D. (Eds.), A high-resolution, multi-proxy record of Pliocene hominin environments in the Kenya Rift Valley: Analysis of the Baringo-Tugen Hills-Barsemoi (BTB) Drill Core. Palaeogeography, Palaeoclimatology, Palaeoecology. Deino, A.L., Tauxe, L., Monaghan, M., Hill, A., 2002. 40Ar/(39)Ar geochronology and paleomagnetic stratigraphy of the Lukeino and lower Chemeron Formations at Tabarin and Kapcheberek, Tugen Hills, Kenya. J. Hum. Evol. 42, 117-40. https://doi.org/10.1006/jhev.2001.0521 deMenocal, P.B., 2004. African climate change and faunal evolution turing the PliocenePleistocene. Earth Planet. Sci. Lett. 220, 3-24. https://doi.c rg/1 ).1016/S0012$821 X(04) 00003-2$

Dunlop, D.J., 2002a. Theory and application of the Day plu. ( M rs / M s versus H cr / H c ) 1. Theoretical curves and tests using titanomagnetit dats. J. Geophys. Res. 107, 2056. https://doi.org/10.1029/2001JB000486

Dunlop, D.J., 2002b. Theory and application of th D y plot ( M rs / M s versus H cr / H c ) 2 . Application to data for rocks, sedimf its. anc soils. J. Geophys. Res. 107, 2057. https://doi.org/10.1029/2001JB00048,

Dupont-Nivet, G., Sier, M., Campisano, '.J., Arrowsmith, J.R., Dimaggio, E.E., Reed, K., Lockwood, C., Franke, C., Hüs in s, ., 2008. Magnetostratigraphy of the eastern Hadar Basin (Ledi-Geraru researc' aren, Ethiopia) and implications for hominin paleoenvironments. Geol. Soc. Am. Spec. Pap. 446, 67-85. https://doi.org/10.113า/201 3.2446(03).

Fisher, R., 1953. Dispes sion on a Sphere. Proc. R. Soc. London. Ser. A. Math. Phys. Sci. 217, $295 \mathrm{LP}-305$.

Foley, R.A., 1994. Specration, extinction and climatic change in hominid evolution. J. Hum. Evol. 26, 275-289. https://doi.org/10.1006/JHEV.1994.1017

Fuller, M., 1969. Magnetic orientation of borehole cores. Geophysics 34, 772-774. https://doi.org/10.1190/1.1440047

Garello, D.I., Deino, A.L., Campisano, C.K., Kingston, J.D., this issue. Geochemical characterization of tephra from the upper Chemeron Formation, Baringo Basin, Kenya, and correlations between outcrop and the Baringo-Tugen Hills-Barsemoi drill core. In: Scott, J.J., Stone, J.R., Sier, M.J., Kingston, J.D. (Eds.), A high-resolution, multi-proxy record of Pliocene hominin environments in the Kenya Rift Valley: Analysis of the Baringo-Tugen Hills-Barsemoi (BTB) Drill Core. Palaeogeography, Palaeoclimatology, 
Palaeoecology.

Gilbert, C.C., Goble, E.D., Hill, A., 2010. Miocene Cercopithecoidea from the Tugen Hills, Kenya. J. Hum. Evol. 59, 465-483. https://doi.org/10.1016/J.JHEVOL.2010.05.005

Gradstein, F.M., Ogg, J.G., Schmitz, M.D., Ogg, G.M. (Eds.), 2012. The Geologic Time Scale, in: The Geologic Time Scale. Elsevier, p. iii. https://doi.org/10.1016/B978-0-444-594259.01001-5

Hagstrum, J.T., Fleck, R.J., Evarts, R.C., Calvert, A.T., 2017. Paleomagnetism and 40 Ar/ 39 Ar geochronology of the Plio-Pleistocene Boring Volcanic Field: Implications for the geomagnetic polarity time scale and paleosecular variation. Phys. Earth Planet. Inter. 262, 101-115. https://doi.org/10.1016/j.pepi.2016.07.008

Harmand, S., Lewis, J.E., Feibel, C.S., Lepre, C.J., Prat, S., Lenobie, A., Boës, X., Quinn, R.L., Brenet, M., Arroyo, A., Taylor, N., Clément, S., Daver, G., Bru şal, J.-P., Leakey, L., Mortlock, R. a., Wright, J.D., Lokorodi, S., Kirwa, C., Kent D. V., Roche, H., 2015. 3.3million-year-old stone tools from Lomekwi 3, West '1.rkana, Kenya. Nature 521, 310315. https://doi.org/10.1038/nature14464

Heller, F., 1977. Rockmagnetic studies of Upper Jırassic linıestones from Southern Germany. J. Geophys. 44, 525-543.

Hill, A., 2002. Paleoanthropological resea ch 'n tw: Tugen Hills, Kenya. J. Hum. Evol. 42, 110. https://doi.org/10.1006/JHEV.200, 7520

Hrouda, F., 1982. Magnetic anisotropy ¿ ${ }^{f}$ rocks and its application in geology and geophysics. Geophys. Surv. 5, 37-82.

Joordens, J.C.A., Vonhof, H.B., ' 'eibc.', C.S., Lourens, L.J., Dupont-Nivet, G., van der Lubbe, J.H.J.L., Sier, M.J., Davic. G.R., Kroon, D., 2011. An astronomically-tuned climate framework for homirin' ${ }^{\prime}$ ir the Turkana Basin. Earth Planet. Sci. Lett. 307, 1-8. https://doi.org/10. 016. i.epsl.2011.05.005

Kingston, J.D., Deino, r. L., Edgar, R.K., Hill, A., 2007. Astronomically forced climate change in the Kenyan Ritt Valley 2.7-2.55 Ma: implications for the evolution of early hominin ecosystems. J. Hum. Evol. 53, 487-503. https://doi.org/10.1016/j.jhevol.2006.12.007

Kirschvink, J., 1980. The least-square line and plane and the analysis of paleomagnmetic data. Geophys. J. R. Astron. Soc. 62, 699-18.

Koymans, M.R., Langereis, C.G., Pastor-Galán, D., van Hinsbergen, D.J.J., 2016. Paleomagnetism.org: An online multi-platform open source environment for paleomagnetic data analysis. Comput. Geosci. 93. https://doi.org/10.1016/j.cageo.2016.05.007

Lisiecki, L.E., Raymo, M.E., 2005. A Pliocene-Pleistocene stack of 57 globally distributed benthic $\delta 18$ O records. Paleoceanography 20. https://doi.org/10.1029/2004PA001071 
McCall, G.J.H., Baker, B.H., Walsh, J., 1967. Late Tertiary and Quaternary sediments of the Kenya Rift Valley, in: Bishop, W.W., Clark, J.D. (Eds.), Background to Evolution in Africa. Chicago University, Chicago, pp. 191-220.

McFadden, P.L., McElhinny, M.W., 1988. The combined analysis of remagnetization circles and direct observations in palaeomagnetism. Earth Planet. Sci. Lett. 87, 161-172. https://doi.org/10.1016/0012-821X(88)90072-6

McPherron, S.P., Alemseged, Z., Marean, C.W., Wynn, J.G., Reed, D., Geraads, D., Bobe, R., Béarat, H.A., 2010. Evidence for stone-tool-assisted consumption of animal tissues before 3.39 million years ago at Dikika, Ethiopia. Nature 466, 857-860. https://doi.org/10.1038/nature09248

Mullender, T.A.T., Velzen, A.J., Dekkers, M.J., 1993. Continuous a ${ }_{1} \cdot \mathrm{ft}$ correction and separate identification of ferrimagnetic and paramagnetic contribut ins $j$ i thermomagnetic runs. Geophys. J. Int. 114, 663-672. https://doi.org/10.1111/.136 )-246X.1993.tb06995.x

Özdemir, Ö., Dunlop, D.J., 1997. Effect of crystal defects a.'d internal stress on the domain structure and magnetic properties of magnetite. J. Teo hys. Res. 102, 20,211-220,224.

Peters, C., Dekkers, M.J., 2003. Selected room temnei ature ınagnetic parameters as a function of mineralogy, concentration and grain siz z. ? nv ,. Chem. Earth 28, 659-667. https://doi.org/10.1016/S1474-7065r ر3) 01 2 )-7

Raymo, M.E., 1994. The Initiation of Nortı "n Hemisphere Glaciation. Annu. Rev. Earth Planet. Sci. 22, 353-383. https://du: org/10.1146/annurev.ea.22.050194.002033

Roberts, A.P., Chang, L., Rowan, C. S. H ring, C.-S., Florindo, F., 2011. Magnetic properties of ssedimentary greigite $\left(\mathrm{Fe}_{3} \mathrm{~S}\right)$ : A.: update. Rev. Geophys. 49, RG1002. https://doi.org/10.1029/2し'10RG000336

Scott, J.J., Chupik, D.T. Deı 10, A.L., Stockhecke, M., Kingston, J.D., Westover, K.S., Lukens, W.E., Deocampo, L.M., Yost, C.L., Billingsley, A.L., Minkara, K.E., Ortiz, K., Cohen, A.S., this issue. Sequence stratigraphic framework for lacustrine transgression-regression cycles in the 3.3-2.6 Ma interval of the Chemeron Formation BTB13 core, Baringo Basin, Kenya Rift Valley. In: Scott, J.J., Stone, J.R., Sier, M.J., Kingston, J.D. (Eds.), A highresolution, multi-proxy record of Pliocene hominin environments in the Kenya Rift Valley: Analysis of the Baringo-Tugen Hills- Barsemoi (BTB) Drill Core. Palaeogeography, Palaeoclimatology, Palaeoecology..

Sier, M.J., Langereis, C.G., Dupont-nivet, G., Feibel, C.S., Joordens, J.C.A., Beck, C.C., Olago, D., Cohen, A., Team, W.S., 2017a. The top of the Olduvai Subchron in a high-resolution magnetostratigraphy from the West Turkana core WTK13, hominin sites and Paleolakes Drilling Project (HSPDP). Quat. Geochronol. 42, 117-129. 
https://doi.org/https://doi.org/10.1016/j.quageo.2017.08.004

Sier, M.J., Langereis, C.G., Dupont-nivet, G., Feibel, C.S., Joordens, J.C.A., Beck, C.C., Olago, D., Cohen, A., Team, W.S., 2017b. The top of the Olduvai Subchron in a high-resolution magnetostratigraphy from the West Turkana core WTK13, hominin sites and Paleolakes Drilling Project (HSPDP). Quat. Geochronol. 42. https://doi.org/https://doi.org/10.1016/j.quageo.2017.08.004

Tauxe, L., Mullender, T.A.T., Pick, T., 1996. Potbellies, wasp-waists, and superparamagnetism in magnetic hysteresis. J. Geophys. Res. Solid Earth 101, 571-583. https://doi.org/10.1029/95JB03041

Vasiliev, I., Dekkers, M.J., Krijgsman, W., Franke, C., Langereis, C.G., Mullender, T. a. T., 2007. Early diagenetic greigite as a recorder of the palaeomagn tic signal in MiocenePliocene sedimentary rocks of the Carpathian foredeep (R( man a). Geophys. J. Int. 171, 613-629. https://doi.org/10.1111/j.1365-246X.2007.03 i60.

Villmoare, B., Kimbel, W.H., Seyoum, C., Campisano, C.s., DiMaggio, E.N., Rowan, J., Braun, D.R., Arrowsmith, J.R., Reed, K.E., 2015. Paleo a thrc pology. Early Homo at 2.8 Ma from Ledi-Geraru, Afar, Ethiopia. Science 347, 135?-5. https://doi.org/10.1126/science.aaa1343

Vrba, E.S., 1995. Paleoclimate and Evolu ${ }^{+}$on w1i Emphasis on Human Origins. Yale University Press, New Haven.

Walker, A., Leakey, R.E., Harris, J.M., `rown, F.H., 1986. 2.5-Myr Australopithecus boisei from west of Lake Turkana, Kın a. i Jature 322, 517.

Zijderveld, J.D.A., 1967. Ac Den agn tization of Rocks: Analysis of Results, Methods in palaeomagnetism. https://'i.org/10.1016/j.neuroscience.2010.03.066.

Figure 1: Map of 've ?ari,go area with geological setting, top left insert shows topographic map of Ea t Africa. Location of BTB13 site (latitude $0.5546 \mathrm{~N}$, longitude 35.9375E). Stratigraphy of this figure is described in Deino at al., 2006 and Kingston et al., 2007.

Figure 2: A) Thermomagnetic experiment showing the typical high-field magnetic moment upon heating (red) and subsequent (blue) cooling in successive temperature ranges measured on Curie balance. Sample BTB13-1A-49Q-3-14 has a depth of 142.99 mbs. B) Non normalized plotted TH IRM demagnetization. Magnetization versus temperature. 
Figure 3: A) Hysteresis curves of samples BTB13-1A-50Q-3-2 (146.64 mbs), BTB131A-68Q-3-2 (196.17 mbs) and BTB13-1A-43Q-1-102 (123.44 mbs), BTB13-1A-7Q-258 (23.86 mbs). A) Day plot of $\mathrm{M}_{\mathrm{sr}} / \mathrm{M}_{\mathrm{s}}$ and $\mathrm{H}_{\mathrm{cr}} / \mathrm{H}_{\mathrm{c}}$ ratios. The solid and dashed lines represent mixing curves of Dunlop (2002a,b), with SD = single domain, $\mathrm{SP}=$ superparamagnetic, and MD = multidomain. The data points (green squares) are from BTB13 core. SD range: $M_{s r} / M_{s} 0.5$ to $1 H_{c r} / H_{c}$ and 1 to 2, PSD rage: $M_{s r} / M_{s} 0.5$ and $0.04 \mathrm{H}_{\mathrm{cr}} / \mathrm{H}_{\mathrm{c}}:$ 2and 5, MD range: $\mathrm{M}_{\mathrm{sr}} / \mathrm{M}_{\mathrm{s}} 0$ to $0.04 \mathrm{H}_{\mathrm{cr}} / \mathrm{H}_{\mathrm{c}}$ : more than 5 .

Figure 4: A) AMS results BTB13 samples with k1, k2 and k, `xis. B) Only k3 axis of BTB samples. C) P, the degree of AMS (k1/k3) plotted agi inst Km, the mean susceptibility. D) Shape parameter T plotted against P t ie digree of AMS (k1/k3). Figure made using Anisoft42 software.

Figure 5: Typical Zijderveld (1967) diagram ex mples of two samples (a, b) with reversed ChRM (red arrow) after reorientat on oi the low temperature overprint to normal directions (blue arrow) and or' $\mathrm{e}^{\mathrm{r}}$ ample of a sample which shows a great circle and for which the two directions ce rld not be fully separated (c, d) Closed/open circles denote projection on a horizontal'se ‘ical plane.

Figure 6: Plotted LT/LC (li v temperature/ low coercivity) corrected ChRM directions of the BTB13 core. Blac' dols are interpreted ChRM directions used for interpretation. Grey dots are normal Thk $\mathrm{M}$ directions within reversed zone and thus are excluded. Black diamonds are dh zctions obtained by great circle analysis. See text for further explanation. For more detail about lithology see Cohen et al., 2016.

\section{Highlights}

- A $228 \mathrm{~m}$ drill core (BTB13) was recovered from a Pliocene sedimentary sequence in the Central Kenya Rift near fossil rich outcrops.

- Paleomagnetic study of the core identified four paleomagnetic reversals.

- Ages of the reversals are consistent with 40Ar/39Ar dating of tephra s from the same core. 